\title{
Morphological Differentiation and Hybridization between Quercus alnifolia Poech and Quercus coccifera L. (Fagaceae) in Cyprus
}

\author{
By Ch. Neophytou ${ }^{1,2,2),}$, G. Palli $^{1)}$, A. Dounavi ${ }^{2)}$ and F. A. Aravanopoulos ${ }^{1)}$
}

(Received 14 ${ }^{\text {th }}$ August 2006)

\begin{abstract}
Analysis of morphological traits was carried out in order to provide insights regarding differentiation and hybridization between two evergreen oak species, the golden oak (Quercus alnifolia Poech) and the holly oak (Quercus coccifera L.) in Cyprus. The holly oak shows a higher degree of morphological diversity, in comparison to the endemic golden oak, which is confined to the ultrabasic rock formations of the Troodos Massif. The parental species can be clearly distinguished. Each species forms both pure and sympatric populations; no significant differences were observed at the within species level. Analysis of mixed stands indicates active but limited genetic introgression and hybridization between the two oaks. Designated hybrids form a distinct group in multivariate space being morphologically closer to the golden oak. Backcrossing events have been implicated from multivariate analysis, while hybrids appear to be more similar to $Q$. alnifolia.
\end{abstract}

Key words: golden oak, holly oak, differentiation, hybridization, genetic introgression, morphological traits, discriminant analysis, PCA.

\section{Introduction}

The genus Quercus L. consists of about 400 to 450 species spread in temperate to semiarid areas across the northern hemisphere (NIXON, 1993). Oaks are characterized by their high adaptability to a range of sites (LEFORT et al., 1998) and have generally uniform reproductive strategies (KUMAR and ROGSTAD, 1998). Due to wind pollination high levels of gene flow are observed, while genetic introgression is considered as extensive within the genus. Oak species tend to maintain their own morphological, genetic and ecological identities, although reproductive barriers between species appear to be weak. Such barriers include non-synchronous flowering and gamete incompatibility, which affect the success of the parental species as male or female parents and thus play a role regarding the direction of genetic introgression (BoAvIDA et al., 2001). Furthermore, natural selection limits the occurrence of sympatric populations; hybrids mostly grow in narrow habitats (MULLER, 1952; SteBbins et al., 1947; RUSHTON, 1993; WILLIAMs et al., 2001).

\footnotetext{
1) Faculty of Forestry and Natural Environment, Aristotle University of Thessaloniki, PO. BOX. 238, Thessaloniki, Greece.

$\left.{ }^{2}\right)$ Forest Research Institute - Baden-Württemberg, Wonnhaldestr. 4, D-79100, Freiburg.

*) Author for correspondence: Telephone: +49-761-4018161, Fax: +49-761-4018133. E-mail: charalambos.neophytou@forst. bwl.de.
}

About 30-35 oak species are evergreen and grow mostly around the Mediterranean basin, in SW Asia and along the west coast of North America (Toumi and LUMARET, 2001). Evergreen oak species are believed to have colonized the mediterranean basin moving westwards from SW China (ZHOU, 1992). Observations regarding hybrids are reported from the whole mediterranean area (ABEL, 1902; NATIVIDADE, 1936; CAMUS, 1938). Two evergreen oak species, Quercus coccifera L. and Quercus alnifolia Poech grow in Cyprus. Q. coccifera belongs to subgenus Sclerophyllodrys, while $Q$. alnifolia belongs to subgenus Cerris O. Schwarz (Schwarz, 1936; CAMus, 1938). Nevertheless, according to TOUMI and LuMARET (2001), both species should be classified to the same cluster of mediterrarranean oaks that corresponds to subgenus Sclerophyllodrys. The holly oak $(Q$. coccifera) has a wide distribution throughout the Mediterranean Sea, whereas the golden oak (Q. alnifolia) is endemic to Cyprus and is restricted to the ultrabasic soils of Mt. Troodos. Q. alnifolia occupies dry habitats in association with Pinus brutia or forms dense maquis in mesic habitats, characterized by deep forest soils (MEIKLE, 1976; BARBÉRO and QUEZEL, 1979). $Q$. coccifera grows on calcareous geological substrate in the southern part of Mt. Troodos reaching the southern coastal zone, while a separate distribution zone exists along the northern coast. However, scarce holly oak stands can also be found in diverse areas on igneous rocks within the distribution area of the golden oak (MEIKLE, 1976). Individuals with evidently intermediate phenotypes and very good growth have been observed in such areas.

Morphological traits have often served as a tool for studying genetic diversity and interspecific differentiation and hybridization in oaks. Especially, analysis of "easy to use" and unambiguous traits could serve as an applicable method for such investigations in practice (Cousens, 1963; Olsson, 1975a, b; RIEselberG and EllSTRAND, 1993; KREMER et al., 2002). Morphological and other adaptive traits might have differentiated faster than isozymes or selective neutral DNA markers (IsHIDA et al., 2003). Furthermore, according to the genic view of speciation, adaptive traits are not transferred from species to species through hybridization in contrast to non adaptive markers (WU, 2001). In our study, we chose to analyze leaf macromorphological traits, which are easy to measure, in order to develop a convenient screening method to discriminate between the golden and the holly oak. By means of a multivariate analysis we investigated differentiation, hybridization and genetic introgression between the two species. Additionally, the most proper characters discriminating the two species were indicated. 


\section{Materials and Methods}

\section{Sampling areas}

Two pure populations (25 samples each) and two transects (100 samples each) including individuals of both parental species were sampled. The pure populations sampling plots were located at least $10 \mathrm{~km}$ away from any stands of the other species in order to minimize the possibility of interspecific crossings. Trees were chosen to be at least $50 \mathrm{~m}$ apart to avoid sampling related individuals. Transects included pure stands of both species at their respective ends and an intermediate zone in the middle, where sympatric populations exist. In total, 100 individuals about $200 \mathrm{~m}$ apart along a $20 \mathrm{~km}$ line were collected for each transect sampling. The chosen sampling plot (PP1) within the golden oak pure population lies on the western slope of Madari Mountain on the Troodos range on diabasic rock formations. The respective location for $Q$. coccifera (PP2) was chosen to be the Ha-Potami and Diarizos river mouth area on calcareous geological substrate. The first transect (TR1) was sampled at the Kambos River valley on the north slope of the Troodos Mountains and the second (TR2) from a line between Prodromos village and the confluence area of the Elias and Diarizos rivers, on the southern slope of Troodos. The geological substrate is mainly igneous (Troodos ophiolithic complex). Sampling areas are presented in Figure 1

\section{Plant material and assessment of leaf morphological traits}

During sampling each plant was characterized as a golden or a holly oak or as a hybrid after an evaluation of its phenotype. The following morphological characteristics were used for an initial classification: pubescence (thick and golden coloured in $Q$. alnifolia, absent in $Q$. coccifera), leaf colour (darker in $Q$. alnifolia, lighter in $Q$. coccifera), teeth (softer in $Q$. alnifolia, sharp in $Q$. coccifera), lamina shape (upside convex in

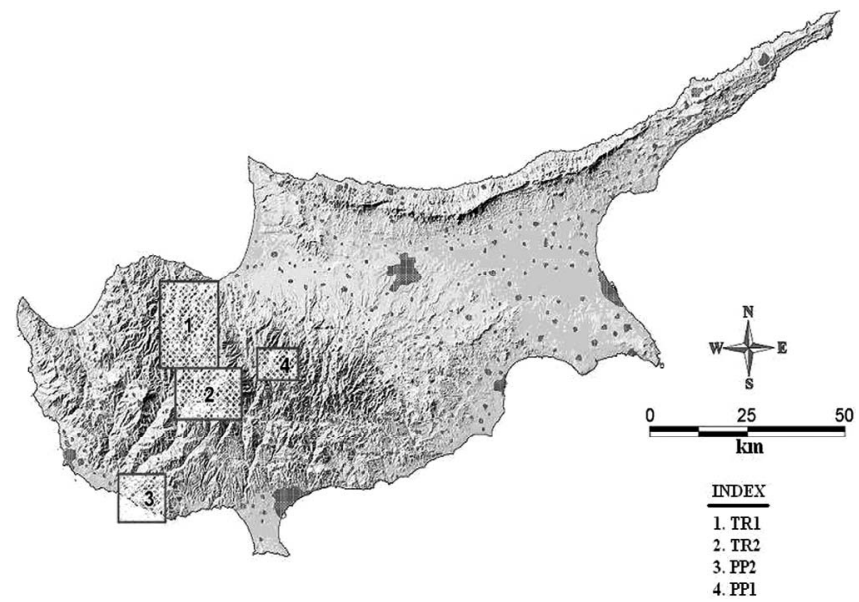

Figure 1. - Location of sampling areas in Cyprus: (1) First transect (TR1): Kambos river valley, on the northern slope of the Troodos Range (altitude 500-1300 m); (2) Second transect (TR2): Confluence area of Elias and Diarizos rivers, on the southern slope of the Troodos Range (altitude 600-1400 m); (3) Holly oak pure population (PP2): Ha-Potami and Diarizos river mouth area (altitude about $100 \mathrm{~m}$ ); (4) Golden oak pure population (PP1): Madari mountain (altitude 1400-1600 m).
$Q$. alnifolia, flat in $Q$. coccifera), nerves (downside standing out and markedly more distinguishable in Q. alnifolia). From each plant 10 leaves from the north side of the crown at a height of $1,50 \mathrm{~m}$ were sampled. Leaves were chosen to be fully expanded, insect and disease free, and were collected from the current year's flush. Leaves were collected at the end of the growing season (mid-July). A total of 2500 leaves were sampled and measured. Discriminative leaf traits were chosen based on botanical desriptions (MEIKLE, 1976). The protocol of leaf morphology assessment was based upon a study discriminting $Q$. petraea and $Q$. robur (KREMER et al., 2002), as well as on ARAVANOPOULOS (2005) with some modifications. One observed variable (pubescence (PU), estimated 1-5), two counted variables (teeth number (TE), side nerve number (UN)) and four leaf size variables (lamina length (LL), lamina width $(\mathrm{LW})$, petiole length (PL), distance from leaf base to the leaf maximum width $(\mathrm{BW})$, measured in $\mathrm{cm}$ ) were assessed. All assessed variables are illustrated in Figure 2. Additionally, the following three leaf shape variables were calculated: distance from leaf base to the leaf widest point / leaf length (BW/LL), lamina width / lamina length (LW/LL), petiole length / lamina length (PL/LL). These ratios, which form independent shape variables, have been used extensively in leaf morphometrics (DICKINSON et al., 1987). The data set consisted of 17500 records.

\section{Data analysis}

Descriptive statistics were computed for all populations. Normality of the data was checked by means of the coefficient of variation (CV) and the Shapiro-Wilk statistic for normality W. Data transformations were performed when normality criteria were not met; logarithmic transformation $\left(\log _{10}\right)$ was successfully

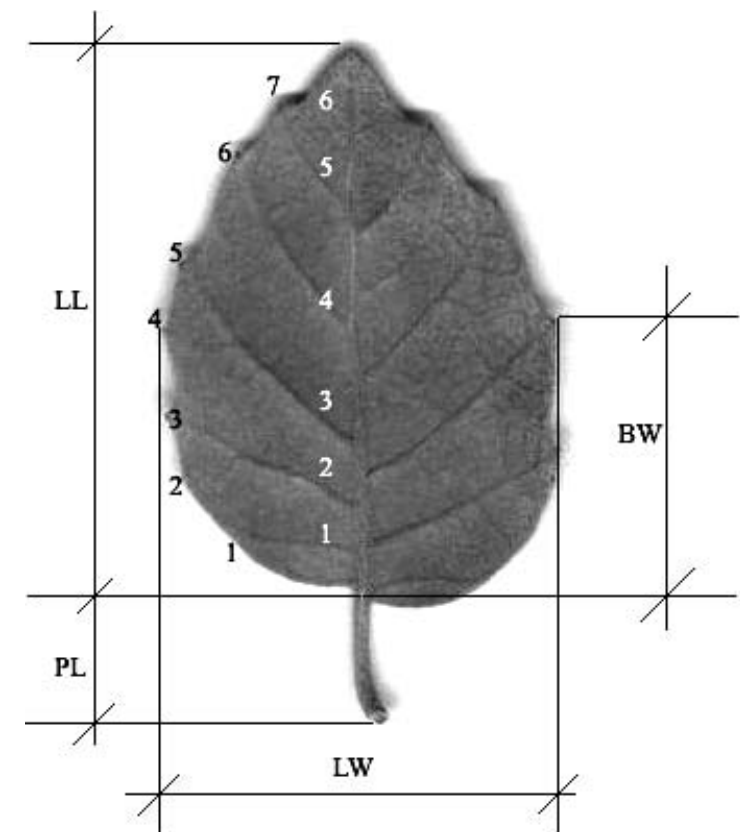

Figure 2. - Presentation of the assessed leaf morphological variables: White numbers: Nerves (counted variable); Black numbers: Teeth (counted variable); LL: Lamina length (measured in $\mathrm{cm}$ ); LW: Lamina width (measured in $\mathrm{cm}$ ); BW: Distance leaf base - leaf maximum width (measured in $\mathrm{cm}$ ); PL: Petiole length (measured in $\mathrm{cm}$ ). 
employed. Linearity and multivariate normality are more closely approximated by logarithms than by the original variables, since logarithms tend to provide components that are independent of scales of measurement and order of magnitude of variances (DICKINSON, 1986).

Multivariate analysis was employed in order to examine the simultaneous contribution of all leaf parameters in discriminating between populations and within populations. Principal Component Analysis (PCA) was performed in order to observe the ordination of groups of variables in principal space. In the field of numerical biology the use of PCA is widespread, since it fits for the analysis of data concerning more than one variable measured for each individual and it results in sensible biological explanation of the results (PIMENTEL, 1979). In component analysis the original variables are transformed to variables that have zero intercorrelations. The transformation rotates the original axes but maintains the original relationships among data points. The new axes define independent patterns of variation infrequently recognized as size and shape variables that should typify the population sampled (PIMENTEL, 1979). PCA was conducted on the correlation matrix since this PCA separates size from shape more effectively than the analysis with a covariance matrix (SOMMERS, 1986). PCA has often been used for elucidating the discriminative power of morphological characters (PANETSOs et al., 1997; ARAVANOPOULOS, 2005).

The genetically defined groups of data (populations) were subjected to a Multivariate Analysis of Variance
(MANOVA) and a Multiple Discriminant Analysis (MDA) (MARRIOT, 1974), in order to see if this classification was in agreement with the leaf data. Initially a MANOVA was done in order to check the significance among groups (test of $\mathrm{H}_{0}$ = equality of group centroids). MDA has two objectives: (1) to explain differences between groups in terms of a linear compound of " $p$ " explanatory variables, which maximize separation and (2) to classify individuals with minimum probability of misclassification. MDA gives insight into the relative importance of variables, which separate categories, the main purpose of the technique being to identify misclassified individuals (LAAR, 1986). The percentage of return (PIMENTEL, 1979) to original groups after the ordination in discriminant space (of their leaf data) is a measure of the true relationship of leaf variables to the taxonomic or genetic groups of plants.

\section{Results}

Individuals from all sampling areas were designated as $Q$. alnifolia, $Q$. coccifera or putative hybrids. Mean values, variance coefficients and 95\% confidence intervals for each one of the measured variables are presented in Table 1. Pubescence, used among other characteristics to distinguish the parental species showed, as expected, a high degree of uniformity within each group. Regarding the dimensional variables, golden oak samples showed higher values in all traits, while in the holly oak a higher variance was observed in the respective variables except petiole length. Among the counted

Table 1. - Mean, coefficient of variation (CV) and confidence interval of the mean (CI) for each one of the morphological traits assessed in this research. For confidence intervals, maximum (upper line) and minimum (lower line) values are given (character codes as explained in Materials and Methods).

\begin{tabular}{|c|c|c|c|c|c|c|c|c|c|}
\hline & \multicolumn{3}{|c|}{ Quercus alnifolia } & \multicolumn{3}{|c|}{ Quercus coccifera } & \multicolumn{3}{|c|}{ Putative hybrids } \\
\hline & mean & $\mathrm{CV}$ & CI & mean & $\mathrm{CV}$ & $\mathrm{CI}$ & mean & $\mathrm{CV}$ & $\mathrm{CI}$ \\
\hline \multirow{2}{*}{ PU } & \multirow{2}{*}{4,95} & \multirow{2}{*}{0,04} & 4,75 & \multirow{2}{*}{1,04} & \multirow{2}{*}{0,19} & 0,84 & \multirow{2}{*}{2,84} & \multirow{2}{*}{0,30} & 1,99 \\
\hline & & & 5,15 & & & 1,24 & & & 3,69 \\
\hline \multirow{2}{*}{ TE } & \multirow{2}{*}{5,79} & \multirow{2}{*}{0,24} & 4,40 & \multirow{2}{*}{6,44} & \multirow{2}{*}{0,28} & 4,64 & \multirow{2}{*}{7,60} & \multirow{2}{*}{0,19} & 6,16 \\
\hline & & & 7,18 & & & 8,24 & & & 9,04 \\
\hline \multirow{2}{*}{ UN } & \multirow{2}{*}{6,57} & \multirow{2}{*}{0,12} & 5,78 & \multirow{2}{*}{8,88} & \multirow{2}{*}{0,17} & 7,37 & \multirow{2}{*}{7,51} & \multirow{2}{*}{0,15} & 6,38 \\
\hline & & & 7,36 & & & 10,39 & & & 8,64 \\
\hline \multirow{2}{*}{ LL } & \multirow{2}{*}{3,99} & \multirow{2}{*}{0,16} & 3,35 & \multirow{2}{*}{2,81} & \multirow{2}{*}{0,21} & 2,22 & \multirow{2}{*}{3,71} & \multirow{2}{*}{0,16} & 3,12 \\
\hline & & & 4,63 & & & 3,40 & & & 4,30 \\
\hline \multirow{2}{*}{ LW } & \multirow{2}{*}{2,99} & 010 & 2,42 & 166 & 024 & 1,26 & 264 & 015 & 2,24 \\
\hline & & 0,19 & 3,56 & 1,00 & 0,24 & 2,06 & 2,04 & 0,13 & 3,04 \\
\hline RW & 191 & 0.19 & 1,55 & 130 & 027 & 0,95 & 176 & 017 & 1,46 \\
\hline Dw & 1,91 & 0,19 & 2,27 & 1,30 & 0,21 & 1,65 & 1,70 & 0,17 & 2,06 \\
\hline PI & 000 & 028 & 0,71 & 038 & 072 & 0,30 & 065 & 035 & 0,42 \\
\hline 12 & 0,99 & 0,20 & 1,27 & 0,30 & 0,22 & 0,46 & 0,03 & 0,35 & 0,88 \\
\hline BW/I & 048 & 011 & 0,43 & 046 & 013 & 0,40 & 047 & 015 & 0,40 \\
\hline DW/LL & 0,40 & 0,11 & 0,53 & 0,40 & 0,13 & 0,52 & 0,41 & 0,15 & 0,54 \\
\hline I W/I I & 075 & 012 & 0,66 & 060 & 016 & 0,50 & 072 & 013 & 0,63 \\
\hline LW/LL & 0,13 & 0,12 & 0,84 & 0,00 & 0,10 & 0,70 & 0,12 & $0,1 J$ & 0,81 \\
\hline PI /I I & 025 & 026 & 0,19 & 014 & 017 & 0,12 & 018 & 036 & 0,12 \\
\hline $1 \mathrm{~L} / \mathrm{LL}$ & & 0,20 & 0,32 & 0,17 & 0,17 & 0,16 & 0,10 & ( & 0,24 \\
\hline
\end{tabular}


Table 2. - Mahalanobis distances among species as revealed by discriminant analysis in pure populations and transects.

\begin{tabular}{|c|c|c|c|c|c|}
\hline From species & $\begin{array}{c}\text { Golden oak } \\
\text { (transects) }\end{array}$ & $\begin{array}{c}\text { Holly oak } \\
\text { (transects) }\end{array}$ & $\begin{array}{c}\text { Putative } \\
\text { hybrids } \\
\text { (transects) }\end{array}$ & $\begin{array}{c}\text { Golden oak } \\
\text { (pure pop.) }\end{array}$ & $\begin{array}{c}\text { Holly oak } \\
\text { (pure pop.) }\end{array}$ \\
\hline $\begin{array}{c}\text { Golden oak } \\
\text { (transects) }\end{array}$ & 0 & 196,953 & 33,453 & 0,257 & 204,724 \\
\hline $\begin{array}{c}\text { Holly oak } \\
\text { (transects) }\end{array}$ & 196,953 & 0 & 72,880 & 199,616 & 2,743 \\
\hline $\begin{array}{c}\text { Putative hybrids } \\
\text { (transects) }\end{array}$ & 33,453 & 72,880 & 0 & 35,595 & 79,438 \\
\hline $\begin{array}{c}\text { Golden oak } \\
\text { (pure pop.) }\end{array}$ & 0,257 & 199,616 & 35,595 & 0 & 207,704 \\
\hline $\begin{array}{c}\text { Holly oak } \\
\text { (pure pop.) }\end{array}$ & 204,724 & 2,743 & 79,438 & 207,704 & 0 \\
\hline
\end{tabular}

variables significant differentiation could be observed in the side nerve number and among the composite variables in the ratio LW/LL.

The MANOVA analysis verified the equality of group centroids, therefore making the MDA approach valid. Mahalanobis distances that were estimated through the MDA analysis are presented in Table 2. The largest values were observed between the parental species from the pure populations. Parental individuals originating from pure populations appear to be morphologically more dinstinct from hybrids, in comparison to parental individuals sampled from transects. The morphological (Mahalanobis) distances between oaks sampled in the pure populations and those sampled in the transects were greater than the respective distances regarding golden oaks. The morphological distances between hybrids and golden oaks were generally smaller when compared to those between hybrids and holly oaks (Table 2).

Regarding the PCA, in a total of ten principal components, the first three explain more than $80 \%$ of the whole variability, indicating the validity of the technique in defining distinct groups. All components were bipolar. The first component (PRIN1) explained 56,4\% of the total variation and showed high eigenvector values for lamina width (LW), petiole length (PL), pubescence (PU) and PL/LL (Table 3). Based on the two first principal components, which represent about $70 \%$ of the total variability, we produced bidimensional PRIN2 = $\mathrm{f}$ (PRIN1) plot diagrams, one including the two trancect populations (Figure 3) and one including all populations (Figures 3, 4). In all cases the parental species could be clearly distinguished from each other. Holly oak individuals showed a distinctly wider dispersal, although their proportion within the sample was lower, compared to the golden oak (Figures 3, 4). A number of designated hybrids was located within the holly or golden oak clusters, while some designated holly or golden oak individuals appeared within the area of the putative hybrids (Figure 4). Finally, individuals originating from pure populations emerged well apart from each other in the respective graphs and were absent from the intermediate plot area where hybrids appeared.

\section{Discussion}

A main finding of this study is the reduced morphological variability of the golden oak compared to the holly oak. This could be attributed to its narrower ecological range, but the former species may also present a lower genetic variation compared to the latter. $Q$. alnifolia is restricted to the ultrabasic soils of the Troodos Mountains, where it forms well adapted populations. On the other hand, $Q$. coccifera grows almost around the whole Mediterranean basin being present in diverse ecosystems, and shows a wide phenotypic variability, which may reflect a greater genetic plasticity. In an isoenzyme study of the mediterranean evergreen oak species, the hypothesis that genetic drift as a result of a founder effect might account for the limited genetic diversity of Q. alnifolia was advanced (TOUMI and LumARET, 2001).

Table 3. - Eigenvectors of the original morphological variables for each one of the three first principal components (character codes as explained in Materials and Methods).

\begin{tabular}{|l|c|c|c|}
\hline & PRIN1 & PRIN2 & PRIN3 \\
\hline PU & 0,385 & $-0,143$ & 0,120 \\
\hline TE & $-0,034$ & 0,499 & 0,385 \\
\hline UN & $-0,297$ & 0,422 & 0,171 \\
\hline LW & 0,343 & 0,343 & 0,239 \\
\hline BW & 0,394 & 0,145 & 0,117 \\
\hline PL & 0,347 & 0,426 & $-0,159$ \\
\hline BW/LL & 0,393 & $-0,046$ & 0,162 \\
\hline LW/LL & 0,135 & 0,332 & $-0,815$ \\
\hline PL/LL & 0,292 & $-0,088$ & $-0,123$ \\
\hline
\end{tabular}




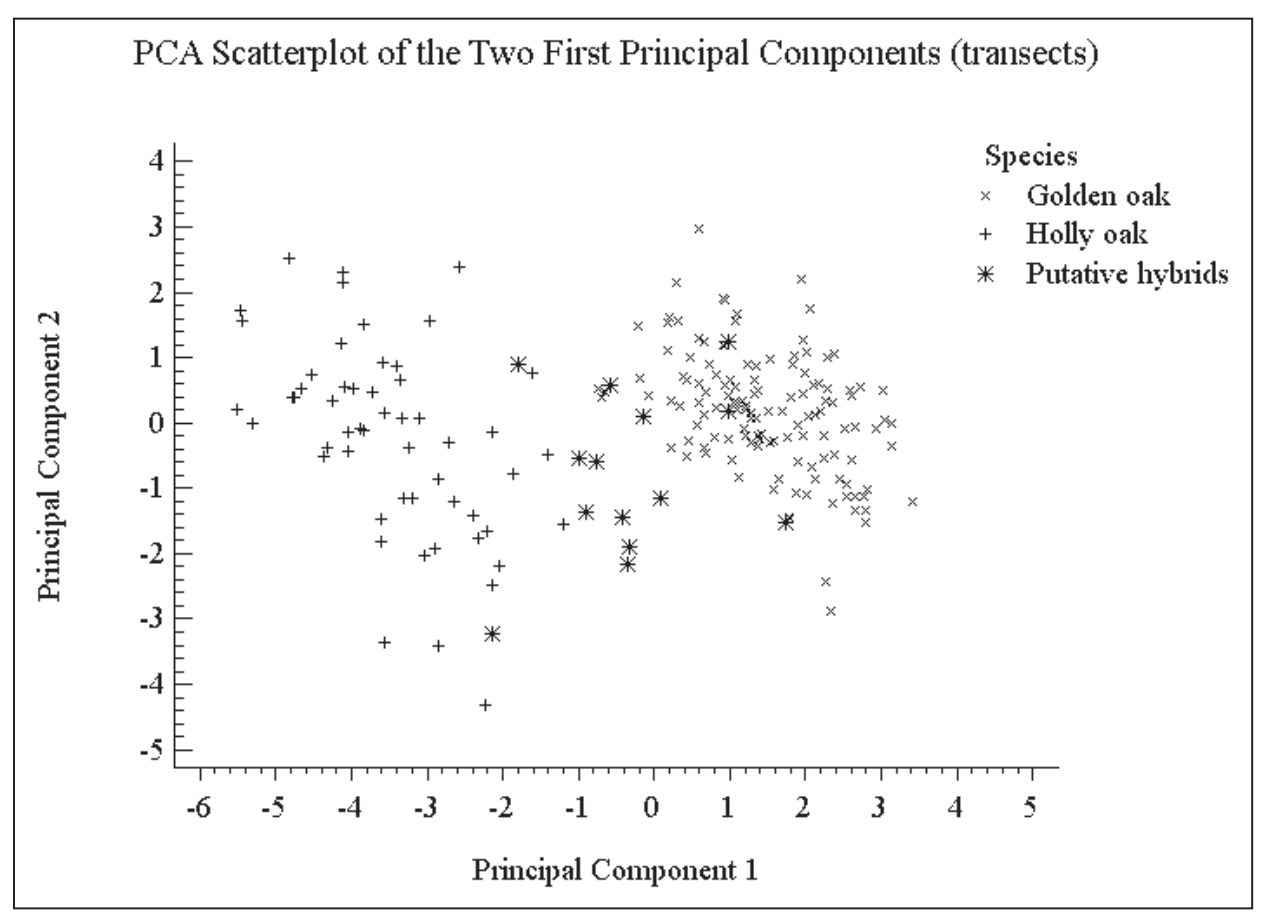

Figure 3. - Scatterplot of the two principal components for the two transects. The parental species form distinct clusters on the plot, while designated hybrids appear in the middle. The holly oak shows a wider dispersal. Overlapping between hybrids and parental species, especially with the golden oak, can be observed.

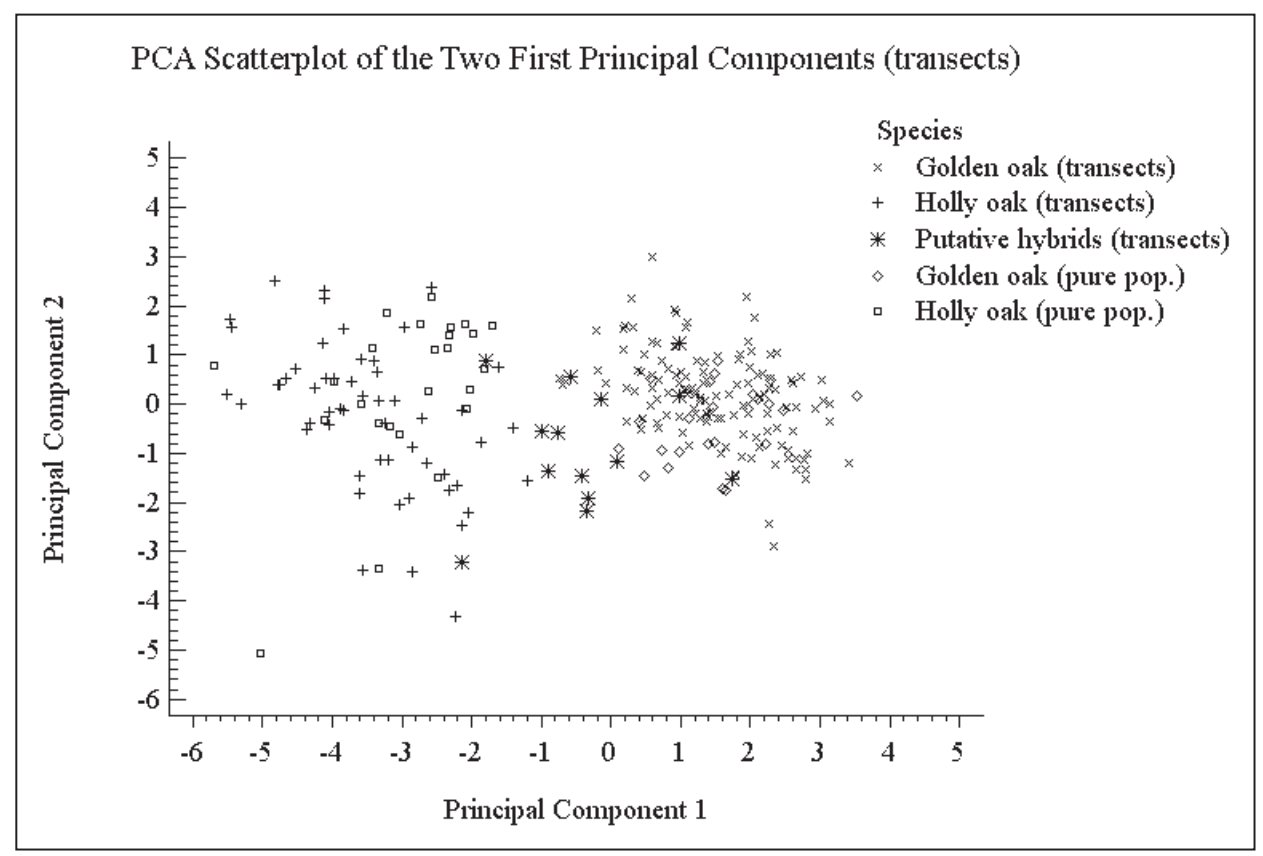

Figure 4. - Scatterplot of the two principal components for all populations. Parental species individuals from pure populations appear well apart from each other, while transect parental species individuals can also be observed in the middle area together with hybrids. A higher degree of overlapping can be observed between designated hybrids and golden oak, compared with holly oak.

Results of the present study provide evidence about hybridization and may suggest genetic introgression. TOUMI and LUMARET (2001), imply a cetrain phylogenetic affinity among $Q$. alnifolia and $Q$. coccifera which deems hybridization and introgression as plausible. The lower morphological (Mahalanobis) distances between the parental species within the transects suggest that active introgression may take place in these areas (Table 2). Nevertheless, low morphological distances between parental species transect populations and pure isolated populations indicate that the two species generally maintain their morphological identities and introgres- 
sion might not be widespread. Mahalanobis distances were larger between holly oak pure and transect populations than between golden oak pure and transect populations, but this could be attributed to the generally higher phenotypic variation of the former species (Tables 1, 2). In the PCA, presence of scarce designated hybrids within the clusters of the parental species and vice-versa support the notion that backcrosses may have taken place in areas of sympatry (Figures 3,4), so that different types of intermediate forms occur. No respective overlapping of the clusters of pure populations with that of hybrids was observed. However, evidence regarding the presence of backcross individuals was not prevalent, precluding an appreciation of the extend of active introgression.

Finally, as revealed from the results, hybrids tend to be morphologically more similar to the golden oak (Table 3, Figures 3, 4). This could be an indication of the directionality of genetic introgression. In their study with controlled interspecific crosses between sessile (Q. petraea) and pedunculate oak (Q. robur), KLEINSCHMIT et al. (1995) showed that leaf morphology of interspecific progenies is more similar to the morphology of the female parent's species. BoAvidA et al. (2001) studied reproductive barriers between the holm $(Q$. ilex) and the cork oak $(Q$. suber), two closely related species to the holly and the golden oak. With the cork oak acting exclusively as pollen donor, a case of unilateral incongruity was revealed. Furthermore, WiLliams et al. (2001) in a study on hybridization between of $Q$. gambelii and $Q$. grisea indicated that environmental stress can increase the probability of hybrid formation by reducing the competitive ability of the male gametes of one species. Directionality of introgression between the holly and the golden oak and investigation of the possibility that golden oak is mainly, or exclusively, the maternal parent could be a subject of further with use of controlled crosses and molecular markers.

\section{Acknowledgments}

This paper is part of a B.Sc. submitted by the first two authors in the Faculty of Forest Science and Natural Environment, Aristotle University of Thessaloniki. Partial financial assistance to the last author in the form of a Cyprus Ministry of Natural Resources - Aristotle University of Thessaloniki Cooperative Grant is gratefully acknowledged. We especially thank Dr. ANDREAS CHRISTOU (Department of Forests, Nicosia) for his kind help in choosing the proper sampling areas and his contribution during the whole research.

\section{References}

ABEL, A. (1902): De quelques Quercus hybrides ou supposés tels, de Quercus ilex et Quercus coccifera. Bull. Acad. Int. Géo. Bot. 3, 129-131.

Aravanopoulos, A. (2005): Phenotypic variation and population relationships of chestnut (Castanea sativa) in Greece, revealed by multivariate analysis of leaf morphometrics. Acta Horticulturae 693: 230-240.

BARBÉRO, M. and P. QuÉzel (1979): Contribution à l' étude des groupements forestiers de Chypre. Documents phytosociologiques IV: 9-34.
BoAvida, L. C., J. P. Silva and J. A. FeiJó (2001): Sexual reproduction in the cork oak (Quercus suber L.). II. Crossing intra- and interspecific barrieres. Sexual Plant Reproduction 14: 143-152.

Camus, A. (1938): Les chênes. Monographie du genre Quercus. Vol. 3. Lechevallier, Paris.

Cousens, J. E. (1963): Variation in some diagnostic characters of the sessile and pedunculate oaks and their hybrids in Scotland. Watsonia 5: 273-286.

Dickinson, T. A. (1986): Topodeme differentiation in Ontario taxa of Crataegus (Rosaceae: Maloideae): leaf morphometric evidence. Can. J. Bot. 64: 2738-2747.

Dickinson, T. A., W. H. PARKer and R. E. Strauss (1987): Another approach to leaf shape comparisons. Taxon 36: $1-20$.

Ishida, T. A., K. HATtori, H. SATO and M. T. KimURA (2003): Differentiation and hybridization between Quercus crispula and $Q$. dentata (Fagaceae): Insights from morphological traits, amplified fragment length polymorphism markers, and leafminer composition. American Journal of Botany 90(5): 769-776.

Kleinschmit, J. R. G., R. BACILIERI, A. Kremer and A. RolofF (1995): Comparison of morphological and genetic traits of pedunculate oak $(Q$. robur L.) and sessile oak (Q. petraea (Matt.) Liebl.). Silvae Genetica 44: 256-269.

Kremer, A., J. L. Dupouey, J. D. Deans, J. Cottrell, U. Csaikl, R. Finkeldey, S. Espinel, J. Jensen, J. Kleinschmit, B. van Dam, A. Ducousso, I. Forrest, U. L. De Heredia, A. J. Lowe, M. Tutkova, R. C. Munro, S. SteinhofF and V. BADEAU (2002): Leaf morphological differentiation between Quercus robur and Quercus petraea is stable across western European mixed oak stands. Ann. For. Sci. 59: 777-787.

KuMAR, A. and S. H. RoGSTAD (1998): A hierarchical analysis of minisatellite DNA diversity in Gambel oak (Quercus gambelii Nutt.; Fagaceae). Molecular Ecology 7: 859-869.

LAAR, VAN A. (1986): Multivariate analysis: A way to better understanding of complexity. 18th I.U.F.R.O. World Congress G.S. D6: 99-112.

Lefort, F., M. Lally, D. Thompson and G. C. Douglas (1998): Morphological traits, microsatellite fingerprinting and genetic relatedness of a stand of elite oaks (Q. robur L.) at Tullynally, Ireland. Silvae Genetica 47: 257-262.

MARRIOT, F. C. H. (1974): The interpretation of multiple observations. Academic Press. London.

Meikle, R. D. (1976): Flora of Cyprus. Bentham Moxon Trust, Royal Botanic Gardens, London .

MulleR, C. H. (1952): Ecological control of hybridization in Quercus: A factor in the mechanism of Evolution. Evolution Vol. 6, No. 2. 147-161.

NATIVIDADE, J. V. (1936): Estudo histológico dos peridermes do hibrido Quercus ilex x Quercus suber. Cont. Pub. Direccão Geral Florestas Aquicolas 3: 343-368.

Nixon, K. C. (1993): Infrageneric classification of Quercus (Fagaceae) and typification of sectional names. Ann. Sci. For. 50. 25s-34s.

OLsson, U. (1975a): A morphological analysis of phenotypes in populations of Quercus (Fagaceae) in Sweden. Bot. Not. 128: 55-68.

OLsson, U. (1975b): The structure of stellate trichomes and their taxonomic implication in some Quercus species (Fagaceae) Bot. Not. 128: 412-424. 
Panetsos, K. P., A. B. Skaltsoyiannes, F. A. Aravanopoulos, K. Dounavi and A. Dimitrakopoulos (1997): Identification of Pinus brutia Ten., P. halepensis Mill. and their putative hybrids. Silvae Genetica 46(5): 253-257.

Pimentel, R. A. (1979): Morphometrics: The multivariate analysis of biological data. Kendell/Hunt Publ. Comp.

Rieselberg, L. H. and N. C. Ellstrand (1993): What can molecular and morphological markers tell us about plant hybridization. Crit. Rev. Plant Sci. 12, 213-241.

Rushton, B. S. (1993): Artificial hybridization between Quercus robur L. and Quercus petraea (Matt.) Liebl. Watsonia 11, 229-236.

ScHWARZ, O. (1936): Entwurf einem naturlichen system der culpuliferen und der gattung Quercus L. Notizbl. Bot. Gart. Berlin. 13: 1-22.
Sommers, K. M. (1986): Multivariate allometry and removal of size with principal component analysis. Syst. Zool. 35: 359-368.

Stebins, G. L., E. B. Matzke and C. Epling (1947): Hybridization in a population of Quercus marilandica and Q. ilicifolia. Evolution 1: 79-88.

TOUMI, L. and R. LUMARET (2001): Allozyme characterization of four mediterrranean evergreen oak species. Biochemical Systematics and Ecology 29: 799-817.

Williams, J., B. William and D. HowaRd (2001): Reproductive processes in two oak (Quercus) contact zones with different levels of hybridization. Heredity $\mathbf{8 7}$, $680-690$

WU, C.-I. (2001): The genetic view of the process of speciation. Journal of Evolutionary Biology 14: 851-865.

ZHoU, Z. K. (1992): Origin, phylogeny and dispersal of Quercus from China. Acta Bot. Yunnanica 14, 227-236.

\title{
Genetic Gain and Diversity under Different Selection Methods in a Breeding Seed Orchard of Quercus serrata
}

\author{
By K. S. KAnG ${ }^{*}$ ) B. H. Cheon, S. U. HAN, C. S. KIM and W. Y. ChoI \\ Korea Forest Research Institute, 44-3 Omokchun, Kwonsun, Suwon, Kyonggi 441-350, Republic of Korea
}

(Received 21 ${ }^{\text {th }}$ August 2006)

\begin{abstract}
Genetic gain and diversity were estimated in a 13year old Quercus serrata breeding seed orchard under three selection (rouging) methods. The selections were based on individual selection, family selection, and family plus within family selection. Genetic gain was for stem volume and gene diversity was estimated by status number concept. Both estimated genetic gain and gene diversity were compared to those before selection and among selection scenarios. Estimated genetic gain for tree volume ranged from $4.0 \%$ to $9.1 \%$ for three selection methods under $50 \%$ selection intensity. Individual selection was better than family selection for retaining higher genetic gain and status number. Family plus within family selection was the best selection method, while individual selection was more efficient at the strong selection intensity. An optimal point, which maximized gain and diversity, was occurred at $50 \%$ selection intensity that would be applied for genetic thinning in the breeding seed orchard of Quercus serrata. The effect of genetic relatedness among families and possible pollen contamination on both genetic gain and gene diversity, although were not studied but their impact, are discussed. The selection method and intensity level applied should be chosen after careful consideration of the impacts on both genetic gain and diversity for seeds produced from the seed orchard.
\end{abstract}

Key words: seedling seed orchards, coancestry, thinning, selection intensity, rouging.

*) Author to whom all correspondence should be addressed: KYUSuK KANG. Tel. +82 31290 1152, Fax +82 31290 1040. E-Mail: kangks@foa.go.kr

\section{Introduction}

Quercus serrata Thunb. is one of the most important oak species as well as among other broadleaves growing in South Korea. Acorns have long been employed as a source of hog feed, tannin, oil and especially food. Edible acorns of $Q$. serrata are frequently used to make acorn flour and acorn jelly because of high tannin contents (KFRI, 1990).

The breeding program of $Q$. serrata started with the selection of 110 plus-trees from natural stands of South Korea. Seedlings were originated from the selected plustrees and used to establish seedling seed orchards. Due to the limited graft availability caused by high root stock-scion incompatibility, the establishment of clonal seed orchards for $Q$. serrata was limited. At present, most of the $Q$. serrata seed orchard was established using the concept of breeding seed orchard (BSO) (BARNES, 1995; DAVID et al., 2003). In the BSO concept, open-pollinated progeny provided the seedlings for progeny test trials that coupled with seed production, as required by the BSO design.

Breeding intensity within the BSO can be individual selection, family selection or pedigree (half- or full-sibs) control. In determining the genetic construction of BSO, the crucial issues are to select parents effectively, avoiding inbreeding and to evaluate precisely the performance of the progeny. Genetic gain depends on the effectiveness of selection that is also dependent on intensity, precision and criteria. 